\title{
A SILICIFIED STROMATOLITIC MICROFLORA FROM THE LATE PRECAMBRIAN OF WEST-CENTRAL BRAZIL AND ITS IMPLICATIONS FOR PROTEROZOIC BIOSTRATIGRAPHY
}

\author{
THOMAS R, FAIRCHILD \\ Departamento de Geologia Geral, IGUSP \\ SANDRA M.R. SUBACIUS \\ Graduate Student, IGUSP \\ IVO KARMANN \\ Undergraduate Student, IGUSP
}

\begin{abstract}
A late or middle Proterozoic microflora of narrow, tubular to septate, probably algal filaments and small-celled algal or bacterial colonies has been found in a silicified stromatolite in the lower Bambuí Group on Cedral Ranch, near São Domingos, Goiás, west-central Brazil. The very small size and simple morphology of the microfossils suggest an age possibly older than 1400 m.y. for the Bambui Group, an age inconsistent with other available geologic and paleobiologic data. An understanding of the biological affinities, paleoecological setting, and timing of silicification of this microflora may clarify this apparent paradox.
\end{abstract}

\section{INTRODUCTION}

The study of microfossils in Precambrian rocks has provided not only much of the basis for understanding biologic evolution prior to the origin of metazoans and metaphytes (ClOUd, 1976; SCHOPF, 1978) but also the potential means for refining the biostratigraphic subdivision of the Proterozoic (SCHOPF, 1977). This paper reports the preliminary results of our study of microfossils preserved in a silicified stromatolite in the lower Bambui Group (Late Precambrian) on Fazenda Cedral ("Cedral Ranch"), near São Domingos, Goiás (GO), west-central Brazil (Fig. 1). This represents only the third find of undoubted Precambrian microfossils in Brazil and extends the geographic range of microfossiliferous rocks of the Bambui Group a full $200 \mathrm{~km} \mathrm{NNE}$ from the closest previously known locality (FAIRCHILD \& DARDENNE, 1978). The simplicity and very small cell size of the Fazenda Cedral microfossils would seem consistent with an age of 1400 m.y. ( $10^{6}$ years) or older for the microflora according to criteria developed by SCHOPF (1977). This, however, is not consistent with the apparently late Proterozoic age indicated for the Bambuí Group by stromatolitic, geologic, and preliminary geochronologic data (DARDENNE, 1979). We offer several ideas here that may resolve this contradiction.

\section{GEOLOGIC SETTING}

The Fazenda Cedral microflora, like the two other silicified Brazilian Precambrian microfloras (FAIRCHILD \& DARDENNE, 1978), occurs in dark-colored, early diagenetic chert within carbonate of the lower Bambu1 Group (Paraopeba Formation in the stratigraphy of SCHOBBENHAUS FILHO AND OTHERS, 1976, or Sete Lagoas Formation in the more detailed scheme of DARDENNE AND OTHERS, 1978, accepted here) (Fig. 1). At Fazenda Cedral, the carbonate consists of beige, magnesian-calcitic or dolomitic limestone which locally contains biostromes of simple columnar and linked stromatolites up to about $30 \mathrm{~cm}$ high. Irregular, but generally concordant, gray 
to black chert nodules and lenses up to $15 \mathrm{~cm}$ thick and several $\mathrm{cm}$ to several $\mathrm{m}$ in breadth locally replace the carbonate. This part of the Bambuí Group was probably deposited in warm, shallow-water and/or intertidal environments (MENEZES FILHO \& MATOS, 1978; ALVARENGA \& DARDENNE, 1978).

The microfossils were found in a darkgray chert sample whose stromatolitic nature, masked macroscopically by the sample's color, is evidenced in thin section by thin stromatolitic laminae and the apparent remains of a filamentous mat (P1.1, figs. 1, 2). This stromatolite is a small (less than $12 \mathrm{~cm}$ high and 7 $\mathrm{cm}$ across), probably cumulate or columnarlayered form similar to other more obvious cherty and calcareous stromatolites from Fazenda Cedral. Similar silicified stromatolites crop out near Formosa, GO, about half-way between the other two localities of silicified Bambuí microfossils, but have not yet yielded microfossils. The common presence of intraformational, flat-pebble breccias around the stromatolites in our samples indicates a sedimentary environment where platey clasts were formed (perhaps in periodically desiccated nearby limey mudflats), transported (by storm waves or tides), and deposited around stromatolites growing in the intertidal or shallow subtidal zones.

The age of the Bambui Group apparently falls somewhere between 620 m.y., the $\mathrm{Rb}-\mathrm{Sr}$ isochron age for anchimetamorphic events in shales near Januária, Minas Gerais (MG) (BONHOMME, 1976), and 1100-1200 m.y., the apparent trend for metamorphic age-dates of the pre-Bambuí basement (W. Teixeira, C. Tassinari, and O. Siga, personal communication, January, 1980). Stromatolites in the group have been studied (see DARDENNE, 1979) but, in our opinion, not sufficiently to justify definitive correlation within a single stromatolite-based biostratigraphic subdivision of the Proterozoic. The presence of Conophyton metula near São Gabriel, GO (DARDENNE AND OTHERS, 1976), seemingly suggests a Middle Riphean age (1350-950 m.y.) for the base of the Bambuí Group, whereas the presence of "gymnosolenid" stromatolites (MARCHESE, 1974; DARDENNE, 1979) and Linella avis (DARDENNE, 1979) comprises presumptive evidence for a Late Riphean age (less than
1000 m.y.; see PREISS, 1976). Dardenne (1979, p. 43) places the base of the Bambui Group at about $950-1000$ m.y. But if the supposedly glaciogenic sediments forming the basal Bambui unit (DARDENNE, 1978) are correlatable with "Infracambrian" glacial deposits throughout the world, then a still younger age, perhaps no more than $750 \mathrm{~m}$.y. (DUNN AND OTHERS, 1971), may be postulated for the Bambui Group. The size and complexity of the previously studied silicified Bambuí microfossils (FAIRCHILD \& DAR DENNE, 1978) suggest an age of less than 1400 m.y. The weight of present evidence thus favors a middle to late Proterozoic age, less than 1200 m.y., for initiation of Bambuí sedimentation.

\section{DISCUSSION OF THE MICROFLORA}

The microflora consists of narrow, tubular to septate filaments, and clustered, smallcelled colonies, and possibly, some larger unicells (Pl. 1). These microfossils are threedimensionally preserved within microscopically honey-colored to light-brown, cryptocrystalline to microcrystalline chert. Colorless fibrous chalcedony fills secondary open spaces. The chert's good preservation led us originally to expect an abundant microflora. Microfossils, however, are generally very rare and characteristically show little contrast with the siliceous matrix (Pl. 1, fig. 1). Nevertheless, in one thin section, loosely intertwined filaments - the probable remains of an algal mat (Pl. 1, fig. 1) - are relatively abundant over a very small area (about $0.25 \mathrm{~mm}^{2}$ ).

The filaments are unbranched, unsheathed, straight, curved, or tangled and occur as rare, isolated fragments (PI. 1, fig. 3) or, as in the loose aggregate mentioned above, oriented generally subparallel to the plane of the stromatolitic laminae. They vary from 2.3 to $3.3 \mu \mathrm{m}$ in diameter, averaging $2.6 \mu \mathrm{m}$ ( 8 filaments measured), and reach more than $100 \mu \mathrm{m}$ in length (incomplete specimen). They most commonly appear tubular, but in some cases faint cross walls are highlighted by tiny, opaque mineral grains, perhaps pyrite (PI. 1, fig. 2); in others, distinct cross walls, marked by slight to deep constrictions in the filament, cut off 
bead-like to cylindrical cells $2.3-5.9 \mu \mathrm{m}$ long (Pl. 1, figs. 4, 5). Lateral walls are thin and uniform, occasionally coriaceous (Pl. 1, fig. 3).

As some filaments present both septate and tubular sections, we believe that most of the $2-3 \mu \mathrm{m}$ wide filaments in this microflora represent a single, originally septate species whose lateral walls were more readily preserved than its cross walls. From the similarity of the filamentous network shown in Pl. 1, figs. 1 and 2, to modern algal (MONTY, 1967; GEBELEIN, 1969) and bacterial mats (DOEMEL \& BROCK, 1974; WALTER AND OTHERS, 1976) and to probable algal mats in other silicified Precambrian stromatolites (see SCHOPF \& FAIRCHILD, 1973; FAIRCHILD, submitted for publication), the majority of these filaments were probably photoautotrophic, prokaryotic mat-builders, most likely blue-green algae, judging from their size.

The small-celled colonies consist of spheroidal to ellipsoidal cells varying from 2.0 to 5.4 (exceptionally to 6.6$) \mu \mathrm{m}$ in diameter and averaging $3.6 \mu \mathrm{m}$ ( 78 measurements). The cells are not tightly appressed, and many give the impression of occurring in pairs (Pl. 1, fig. 10). Vestigial intracellular remains are not known, even though these colonies are the best preserved of the Fazenda Cedral microfossils. The colonies were apparently held together by an amorphous organic matrix. Individual colonies are generally elongate and rounded with elliptical to quadrate outlines and maximum dimensions between 20 and $30 \mu \mathrm{m}$; they frequently occur within small clusters no more than $80 \mu \mathrm{m}$ across. These microfossils may represent planktonic algae that settled onto the stromatolite, benthic algae growing within or on the stromatolite, or bacteria dependent upon organic components released during degradation of the algal mats.

The colonies bear greatest resemblace to members of Palaeoanacystis Schopf, 1968, and Myxococcoides Schopf, 1968, especially to those in the $1400-1600$ m.y.-old McArthur Group of northern Australia. For example, they share such characteristics as cell and colony shape, as well as clustered habit, with Palaeoanacystis plumbii Muir, 1976, from the Amelia Domolite (MUIR, 1974, 1976) and the Balbirini Dolomite (OEHLER, 1978), though $P$. plumbii has smaller cells (average diameter $2.5 \mu \mathrm{m})$. Other potential, but less favored affinities may be with Myxococcoides kingii Muir, 1976, from the Barney Creek microflora (also in the McArthur Group) (OEHLER, 1977) and with other members of Myxococcoides and fragments of Eoentophysalis belcherensis from the Balbirini Dolomite (OEHLER, 1978).

Still rarer elements in the microflora include narrower filaments; small clusters of cells and unicells probably derived from colonies like those mentioned above; and an apparently flaccid spheroid $12 \mu \mathrm{m}$ in diameter (P1. 1, fig. 6), possibly representing a planktonic or benthic unicellular alga or simply an abandoned algal sheath.

\section{COMPARISON WITH OTHER SILICIFIED MICROFLORAS FROM THE BAMBUI GROUP}

The two most abundant morphotypes of the Fazenda Cedral microflora are morphologically similar to microfossils previously described from the lower Bambui Group near São Gabriel, GO, and Unaí, MG, but differ in size, perhaps significantly, from their closest counterparts in these microfloras. For example, filaments in the silicified stromatolites from Unai are more characteristically septate and smaller (less than $2 \mu \mathrm{m}$ in diameter) (FAIR. CHILD \& DARDENNE, 1978, P1. 1, fig. 3) than the Fazenda Cedral filaments. The colonial forms mentioned above are reminiscent of groupings of small cells in chert from São Gabriel (FAIRCHILD \& DARDENNE, 1978, Pl. 1, Figs. 9-11) but consist of slightly larger cells. On the other hand, some colonies from São Gabriel (FAIRCHILD \& DARDENNE, 1978, P1, 2, figs. 13-16) possess larger cells than those in the Fazenda Cedral colonies.

\section{THE BIOSTRATIGRAPHIC PARADOX OF THE FAZENDA CEDRAL MICROFLORA}

SCHOPF (1977) recently identified an important Precambrian biostratigraphic boundary at about 1400 m.y. ago on the basis of the 
size and complexity of microfossils in silicified stromatolitic microfloras. The Fazenda Cedral microflora, as presently known, contains only very small, simple microfossils and resembles microfloras older than 1400 m.y. old (e.g. the McArthur Group microfloras) much more than younger, more diverse ones such as the less than 1000 m.y.-old Bitter Springs (SCHOPF, 1968; SCHOPF \& BLACIC, 1971) and Skillogalee microfloras (SCHOPF \& FAIRCHILD, 1973; FAIRCHILD, submitted for publication) from Australia. In fact, when cell size and complexity are examined, the Fazenda Cedral microflora seems considerably "more primitive" than the other, stratigraphically equivalent, silicified Bambui microfloras, both of which have significant proportions of spheroidal microfossils much larger than any yet found at Fazenda Cedral (FAIRCHILD \& DARDENNE, 1978). These results are surprising when one considers the arguments presented earlier suggesting an age of less than 1100-1200 m.y. for the oldest Bambui sediments.

To explain this apparent paradox, we must first remember that our study is based on a single, poorly fossiliferous hand sample, so that research on additional material could reveal a better preserved, more abundant, and more diverse microflora, one possibly comparable in complexity and range of cell sizes to the São Gabriel and Unai microfloras. Other possible explanations are that. the Bambui Group is really older than 1400 m.y. or that Schopf's preliminary biostratigraphic limits in the Proterozoic require more precise definition. However, the contrast between the good preservation of the chert and the poor organic preservation and rarity of the microflora suggests, as a working hypothesis, that silicification may have taken place late in diagenesis, perhaps after most of the original microbiota had been obliterated by chemical and bacterial degradation. Hence, the only microorganisms preservable under such conditions would have been unusually resistant forms (or those that had fortuitously escaped destruction) and possible elements of a bacterial microflora that thrived in the decomposing organic matter. If the filamentous microfossils and the $12-\mu \mathrm{m}$ spheroid represent degraded remnants of the original mat, and the colonies - the best preserved of the Fazenda Cedral morphotypes - represent the bacterial microflora, then any statistical or qualitative study of the microflora is bound to be biased by the more primitive evolutonary status of the more abundant, naturally small-celled (SCHOPF, 1977), "simple bacterial microflora". Consequently, such study inadvertently may suggest an age older than 1400 m.y., the apparent limit between purely prokaryotic, small-celled older microfossil assemblages and more diverse, mixed younger prokaryotic-eukaryotic assemblages in silicified stromatolites (SCHOPF, 1977).

\section{CONCLUSIONS}

The present discovery is important because besides representing only the third find of undoubted Prepcambrian microfossils in Brazil, it extends the geographic range of Bambuí microfossils $200 \mathrm{~km}$ NNE from São Gabriel, GO, and about $260 \mathrm{~km} \mathrm{~N}$ from Unaí, MG, thereby delimiting an area of approximately $13,000 \mathrm{~km}^{2}$ where careful collecting will almost certainly uncover new, well-preserved, abundant silicified microfloras.

Second, as both this and the Unaí microfloras occur in stromatolites, future study may provide a better understanding of the biological basis for the apparent evolution of stromatolite morphologies through Proterozoic time.

Finally, the Fazenda Cedral microflora also raises an important question regarding the application of criteria developed by SCHOPF (1977) for defining provisional biostratigraphic limits in the Proterozoic based on silicified stromatolitic microfloras: namely, to what extent do 1) the degree of study, 2) quality of preservation, 3) timing of silicification, 4) decomposition of the original mat-forming microbiota prior to silicification, 5) and preservation of secondary, bacterial microfloras influence paleobiological and biostratigraphic conclusions drawn from the statistical analysis of cell size and the qualitative study of cellular morphologies of such silicified microfossil assemblages? In the present case, this question will be answered only when all three silicified Bambuí microfloras are better known. The reader's attention is drawn to KNOLL \& GOLUBIC'S (1979) recent article that explores a similar theme. 


\section{ACKNOWLEDGEMENTS}

This research has been partly funded by grants from the Fundação de Amparo à Pesquisa do Estado de São Paulo to T.R.F. (Grant no 78/1517) and to S.M.R.S. (Bolsa de Iniciação Científica no 77/851). Samples were collected by I.K. during the "Goiás '78" and "Goiás '79" speleological expeditions of the Centro Excursionista of USP, and by G.L.N. Gusso, on the property of Mr. P.C. de Oliveira. We have also benefited from discussions with O. Siga, C. Tassinari, and W. Teixeira of
RADAMBRASIL. To all those involved we express our grateful appreciation.

\section{APPENDIX}

The microfossils illustrated in Pl. 1, figs. $1-6,8-10$, are found in thin section GP/L-3T126 and those shown in Pl. 1, fig. 7, in thin section GP/L-3T-127, both cut from hand sample GP/3T-1200. Figured material and hand sample are housed in the Paleontological Collections of the IG USP.

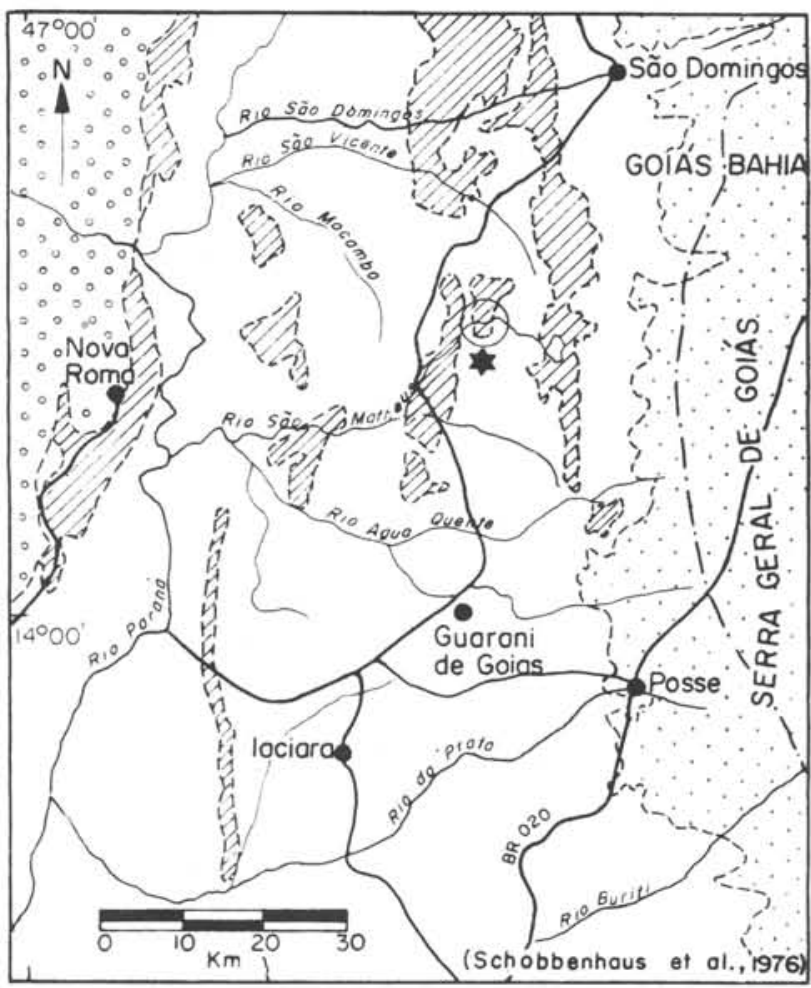

\section{GEOLOGIC SETTING OF THE FAZENDA CEDRAL MICROFOSSILS}

\section{LEGEND}

$\because$ Cretoceous sedimentary rocks.

\section{UPPER PRECAMBRIAN}

BAMBUI GROUP

\section{VIJ Poraopeba Formation dolomitic limestones \\ Poroopeba Formation:} other lithologies $\because$ Arai Group

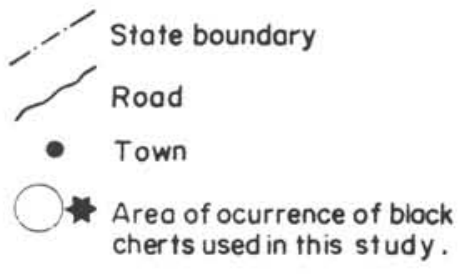

Fig. 1 - Geologic setting of the Fazenda Cedral microfossils.

\section{DESCRIPTION OF PLATE 1 (Following page)}

Transmitted light micrographs of microfossils in thin sections of chert from the lower Bambui Group, Fazenda Cedral, near São Domingos, Goiás. Figs. 3-5 are photomontages. Scale in fig. 1 also serves figs. 8-9; scale in fig. 2 serves all other figures.

Figs. 1, 2 - Overview and close-up of an aggregate of narrow filaments probably representing the vestiges of the original mat-forming microbiota.

Fig. 3 - Broken and pinched, isolated fragment of a tubular-appearing, slightly coriaceous filament.

Figs. 4, 5- Clearly septate filaments found near filaments shown in figs. 1 and 2.

Fig. 6a, b- "Deflated" spheroidal microfossil.

Figs. 7-10 - Clustered, small-celied colonies. Fig. 9 is an overview of the colony illustrated in the focal series presented in fig. 10a-f. 


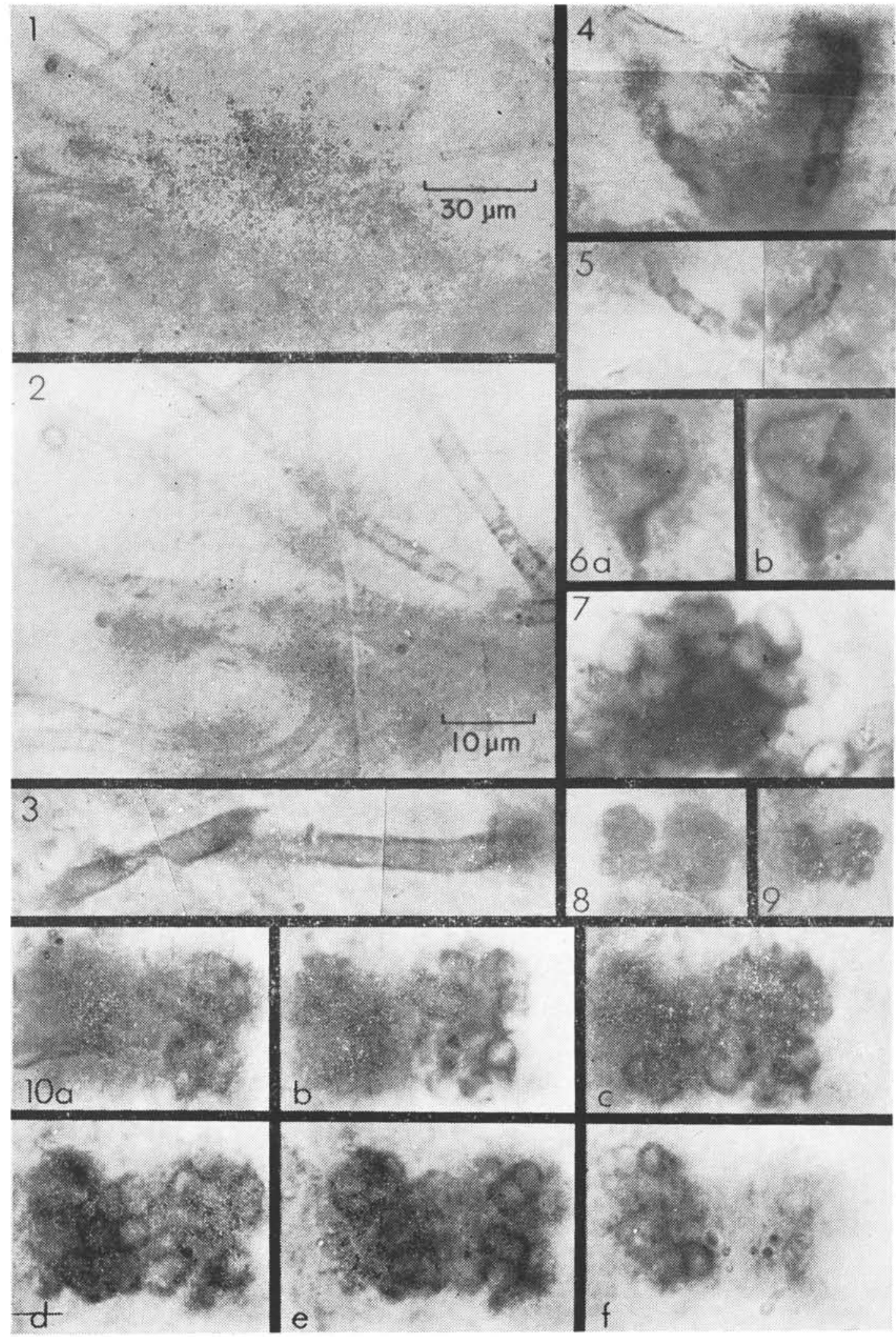




\section{BIBLIOGRAPHY}

ALVARENGA, C.J.S. de, \& DARDENNE, M.A. - 1978 - Geologia dos Grupos Bambui e Paranoá, na Serra de São Domingos, $M G$. XXX Congr. Bras. Geol., Recife, Soc. Bras. Geol., Anais 2:546-556.

BONHOMME, M.G. - 1976 - Mineralogie des fractions fines et datations rubidium-strontium dans le Groupe Bambui, MG, Brésil. Rev. Bras. Geociênc. 6:211-222.

CLOUD, P. - 1976 - Beginnings of biospheric evolution and their biogeochemical consequences. Paleobiology 2: 351-387.

DARDENNE, M.A. - 1978 - Sintese sobre a estratigrafia do Grupo Bambui no Brasil central. XXX Congr. Bras. Geol., Recife, Soc. Bras. Geol., Anais 2: 597-610.

DARDENNE, M. - 1979 - Les mineralisations de plomb, zinc, fluor du Proterozoique superieur dans le Brésil central. These de Doctorat d'Etat és Sciences Naturalles, Université Pierre et Maria Curie, Paris. 251p. 23 pls.

DARDENNE, M.A., FARIA, A. \& ANDRADE, G.F. - 1976 (1977) - Occurrence de stromatolites columnaires dans le Groupe Bambui (Goiás, Brésil). Acad. Bras. Ciênc., Anais 48 (3): 555-566.

DARDENNE, M.A., MAGALHÃES, L.F. \& SOARES, L.A. - 1978 - Geologia do Grupo Bambui no vale do Rio Paranã (Goiás). XXX Congr. Bras. Geol., Recife, Soc. Bras. Geol., Anais 2: 611-621.

DOEMEL, W.N. \& BROCK, T.D. - 1974 - Bacterial stromatolites: origin of laminations. Science 184: 1083-1085.

DUNN, P.R., THOMPSON, B.P. \& RANKAMA, K. - 1971 - Late Precambrian glaciation in Australia as a stratigraphic boundary. Nature 231:498-502.

FAIRCHILD, T.R. - Submitted for publication. The geologic setting and paleobiology of a Late Precambrian stromatolitic microflora from South Australia. Univ. Calif. Publ, Geol. Sci.

FAIRCHILD, T.R. \& DARDENNE, M.A. - 1978 - First report of well-preserved Precambrian microfossils in Brazil (Paraopeba Formation, Bambui Group, near Brasilia). Inst. Geociên., Univ. S. Paulo, Bol. IG 9:62-68.

GEBELEIN, C.D. - 1969 - Distribution, morphology, and accretion rate of recent subtidal algal stromatolites, Bermuda. Jour. Sed. Petrology 39: 49-69.

KNOLL, A.H. \& GOLUBIC, S. 1979 - Anatomy and taphonomy of a Precambrian algal stromatolite. Precambrian Res. 10: 115-151.

MARCHESE, H.G. - 1974 - Estromatolitos "gymnosolenidos" en el lado oriental de Minas Gerais, Brasil. Rev. Bras. Geociênc. 4:257-271.

MENEZES, FILHO, N.R. de, \& MATOS, G.M.M. de - 1978 - Formação Paraopeba - estruturas primárias caracterizantes de ambiente deposicional em plataforma carbonática. XXX Congr. Bras. Geol., Recife, Soc. Bras. Geol., Anais 2: 824-837.

MONTY, C.L.V. - 1967 - Distribution and structure of Recent stromatolitic algal mats, eastern Andros Island, Bahamas. Soc. Géol. Belgique, Ann. 90 (3): 55-100, 19 pls.

MUIR, M.D. - 1974 - Microfossils from the Middle Precambrian McArthur Group, Northern Territory, Australia. Origins of Life 5: 105-118.

MUIR, M.D. - 1976 - Proterozoic microfossils from the Amelia Dolomite, McArthur Basin, Northern Territory. Alcheringa 1: 143-158.

OEHLER, D.Z. - 1978 - Microflora of the Middle Proterozoic Balbirini Dolomite (McArthur Group) of Australia. Alcheringa 2: 269-309.

OEHLER, J.H. - 1977 - Microflora of the H.Y.C. Pyritic Shale Member of the Barney Creek Formation (McArthur Group), Middle Proterozoic of northern Australia. Alcheringa 1:315-349. 
PREISS, W.V. - 1976 - Intercontinental correlations. In Walter, M.R. (ed.). Stromatolites. Elsevier Sci. Publ. Co., Amsterdam. p. 359-370.

SCHOBBENHAUS FILHO, C., BRUNI, M.A., CORDANI, U.G., CAMPOS, D.A. \& CAMPOS, D.R.B. - 1976 Carta geológica do Brasil ao milionésimo. Folha de Brasilia (SD-23). Dep. Nac. Prod. Min., Brasília, 163p.

SCHOPF, J.W. - 1968 - Microflora of the Bitter Springs Formation, Late Precambrian, central Australia. Jour. Paleont. 42:651-688.

SCHOPF, J.W. - 1977 - Biostratigraphic usefulness of stromatolitic Precambrian microbiotas: a preliminary analy. sis. Precambrian Res. 5: 143-173.

SCHOPF, J.W. - 1978 - The evolution of the earliest cells. Sci. Amer. 239 (3): 84-102.

SCHOPF, J.W. \& BLACIC, J.M. - 1971 - New microorganisms from the Bitter Springs Formation (Late Precambrian) of the north-central Amadeus Basin, Australia. Jour. Paleont. 45: 925-960.

SCHOPF, J.W. \& FAIRCHILD, T.R. - 1973 - Late Precambrian microfossils: a new stromatolitic biota from South Australia. Nature. 242:537-538.

WALTER, M.R., BAULD, J. \& BROCK, T.D. - 1976 - Microbiology and morphogenesis of columnar stromatolites (Conophyton, Vacerrilla) from hot springs in Yellowstone National Park. In Walter, M.R. (ed.). Stromatolites. Elsevier Sci. Publ. Co., Amsterdam. p. 273-310.

\title{
ESTROMATOLITOS EM DOLOMITOS DO GRUPO MACAÚBAS (SUPERGRUPO SĀO FRANCISCO) NA REGIĀO DE CONSELHEIRO MATA, M.G.
}

\author{
WALTER U. SCHÖLL \\ Universidade Federal do Paraná \\ CELSO ANTONIO CAMPOLIM FOGAÇA \\ Centro Geologia Eschwege
}

Até a presente data as referências sobre estromatólitos em rochas do Supergrupo São Francisco são na sua grande maioria restritas a rochas carbonáticas do Grupo Bambuí.

Foi descrito um ponto de dolomitos com estromatolitos na borda Leste da Serra do Espinhaço (SCHÖLL, 1976). Na região entre Conselheiro Mata e Rodeador, M.G. foram encontrados numa seqüência de aproximadamente 200 metros de espessura, diversas estruturas algais:

a.) Estromatólitos estratiformes (Tipo LLH - C, Logan et al., 1964):

Trata-se de finos níveis irregulares ondulados com espessura milimétrica em cada unidade tendo-se geralmente vários níveis sucessivos. A espessura total geralmente fica inferior a $10 \mathrm{~cm}$. Estas faixas decimétricas podem se repetir diversas vezes na seqüência.

Localmente desenvolvem-se estromatólitos colunares (tipo SH, Logan et al., 1964), não ramificados de estrutura interna convexa, a partir dos estromatólitos estratiformes. O espaço entre cada colônia é decimétrico a métrico. Uma classificação mais detalhada destes estromatólitos não foi possível devido ao seu estado de conservação.

b.) Estromatólitos colunares

b.1.) Grupo Conophyton

Estromatólitos deste tipo acham-se em boas exposições em diversos pontos ao longo da estrada de ferro e da estrada de rodagem que 